\title{
Nation Branding as a Strategic Marketing Approach to Foreign Direct Investment Promotion: The Case of Zimbabwe
}

\author{
Tafadzwa Matiza \\ University of Limpopo, Turfloop Campus, South Africa \\ E-mail:matizata@hotmail.com \\ Olabanji. A. Oni \\ University of Limpopo, Turfloop Campus, South Africa \\ E-mail: olabanji.oni@ul.ac.za
}

Doi:10.5901/mjss.2013.v4n13p475

\begin{abstract}
This study investigated the potential utilisation of nation branding as a government driven investment promotion approach aimed at attracting foreign direct investment to Zimbabwe. This study used both primary and secondary data. A desk research was conducted to collect secondary data from academic publications and journals, while qualitative primary data collection was semi-structured in nature, utilising an interview schedule to conduct in-depth elite interviews. These interviews were recorded for post interview verbatim transcription. A combination of non-probability sampling techniques were used to establish the final sample frame of 9 key informants for the study from a universal population of 11 investment promotion related organisations in Zimbabwe. The study employed the hermeneutic approach to data analysis to analyse the empirical qualitative data generated from the interviewing process. As a result of this study it emerged that subjectively, the negative image that Zimbabwe has as a country and as an investment destination has a causal effect on the ability of the country to attract foreign direct investment. It also emerged that key stakeholders in Zimbabwe perceive nation branding as a panacea to the image-related challenges of investment promotion for Zimbabwe.
\end{abstract}

Keywords: Foreign direct investment, investment promotion, nation branding, nation image, Zimbabwe,

\section{Introduction}

With Foreign Direct Investment (FDI) into Africa set to double by 2014 to between US $\$ 75$ and US\$100 Billion Sulaiman (2012), one can understand why Zimbabwe's Medium Term Plan (MTP) 2011-2015 identifies foreign direct investment as the crux of growing and transforming Zimbabwe into a globally competitive economy, thereby reducing poverty, increasing employment opportunities and improving the country's Gross Domestic Product (GDP) position. However, one of the specific post 1998-2008 crisis challenges that Zimbabwe's MTP (2011) faces is the enduring negative image the country has, as an investment destination. Media headlines about Zimbabwe can be described as contradictory at best, with the country being associated with headlines such as, "Zim ranks top three African Investment Destinations" (New Ziana, 2012), "Zim a destination for the brave" (Zimbabwe Independent Newspaper, 2012), and more recently "Unabated investor sabotage of investor confidence" (Zimbabwe Independent Newspaper, 2013).

Zimbabwe is emerging from a protracted economic crisis and relative international isolation. However, growing competition amongst countries for investment capital, means that today a negative image as a place for investment, is far more harmful than ever before, and given Zimbabwe's enduring negative image, it is not a major FDI destination in Africa, let alone the world. The principle barrier to the attraction of FDI to Zimbabwe is the negative perception that exists about the country as an investment destination, and this is due to Zimbabwe's marred international image after more than a decade of socio-political and economic instability.

An existing image or perception of a country according to Bellosso (2010) is that country's nation brand, with a nation brand being viewed as a representation or the enduring reputation of a specific country. The nation brand can also be seen as the unique value position of a country, a tool to raise people's interest in investing, visiting or doing business in a particular country. As Fan (2009) points out the external audience defines a nation's image, with their perceptions being primarily based on stereotypes, personal experience and the media. 
There has been a shift in the debate amongst academics and policy-makers alike, from whether or not nations should actively try to attract investment to their nations, to how nations can attract FDI to their economies (Kazembe \& Namizinga, 2007). The how of investment promotion, is a field of research in its own right, and seminal research by Wells and Wint (2000) in investment promotion suggests that many governments have adopted proactive marketing techniques in a bid to attract FDI to their economies. Promotion techniques for investment attraction consist of, information provision to potential investors, the creation of an attractive image of the country as an investment destination, and the provision of services to potential investors. With this in mind, it was the aim of this study to establish the significance of nation images in the promotion of FDI, with particular reference to the case of Zimbabwe and the potential panacea thereof.

Negative or weak nation images are a particular obstacle in investment promotion for most African nations and in the case of Zimbabwe the key questions probed in this paper are:

- What is nation branding and what contribution does nation branding make in the facilitation of foreign direct investment promotion?

- Do the relevant government and private sector stakeholders in Zimbabwe view nation branding as a potential investment promotion approach for Zimbabwe?

- Is nation branding a feasible strategic image promotion strategy for Zimbabwe, to attract Foreign Direct Investment (FDI) into the country?

This paper presents the findings of a broader study which investigated the potential utilisation of nation branding as a strategic investment promotion tool for the Zimbabwean government. This paper sought to establish the relationship between the image of a nation as an investment destination and its ability to attract FDI, as well as the potential role of nation branding as an approach thereof, drawing from the Zimbabwean experience.

\section{Literature Review}

\subsection{Theoretical Framework}

This study adopted the functionalist perspective to nation branding, a perspective which according to Kaneva (2011), is based on a technical - economic studies approach to nation branding, and is the preserve of nation branding practitioners and marketing academics alike. After a review of 186 publications, Kaneva (2011), found that there are primarily three distinct approaches to nation branding, namely; technical - economic approach, political approach, and cultural approach, before concluding that, "The discourse of nation branding finds its strongest representation in the field of marketing." (Kaneva, 2011:120).

The functionalist approach views nation branding as a strategic tool for enhancing a nation's competitive advantage, centred on the argument that, parallels can be drawn between the creation and management of nation images, and the more traditional practice of product and corporate branding.

As Kaneva (2011) elucidates, the technical-economic approach is based on the following three fundamental assumptions, which are management and marketing oriented:

- The global market is homogenous, characterised by global competition amongst nations.

- National welfare is defined by the ability of a nation, to secure economic competitive advantage, with nation branding assuming the role of the tool utilised by nations to attract investment, tourists, human capital or trade.

- Based on the former and later assumptions, the technical-economic approach avows that parallels can be drawn, between nations and brands, and that this premise is both warranted and necessary.

The assumptions that Kaneva (2011) outlines above, refer to the need for nations to differentiate themselves in a globalised marketplace, for instance, the financial world's reference to key African financial hubs, as African Lions, or the reference to the Asian Tigers, mostly quoted in financial publications when referring to well performing Asian nations. With this 'differentiation' in mind, the technical - economic approach, therefore, underpins the approach of this study, which sought to explore nation branding as a promotional tool, for the attraction of FDI (Foreign Direct Investment) into Zimbabwe. The approach is particularly relevant to the study as many countries, due to global forces, find it necessary to proactively strategise, and brand themselves to augment their images, to secure economic competitive advantage, in investment promotion (Porter, 1989).

\subsection{Zimbabwe as an investment Destination}

The decade ending 2008 marked a 'dark age' in the recent history of Zimbabwe, and although Zimbabwe's socio-political 
challenges were multi-faceted at the time, the political intolerance, and general economic decay, emanating from that period are still the hallmark of Zimbabwe's current image. The period between 1998 and 2008 is referred to in the country's MTP 2011-2015 as the, "lost decade", and as a result of this period, one of Zimbabwe's main challenges is the negative image the country has, as an investment destination, due to the 'perceived' prevailing socio-political challenges stemming from that period.

According to the MTP 2011-2015, Zimbabwe's main challenges during this period were severe macro-economic instability (in 2008, Zimbabwe's official annual inflation was $231,000,000 \%$ with monthly inflation in July at $1800 \%$ ); severe shortages in basic utilities including electricity, fuel, water and food commodities both basic and non-basic; significant challenges for business, including foreign currency shortages, loss of skilled labour and unreliable energy supplies; a marked decline in the tourism sector performance, "largely as a result of the negative publicity the country was facing."; as well as wholesale de-industrialization.

Although Zimbabwe's investment environment is characterised by a market driven economy with abundant natural resources; well developed infrastructure; access to world and regional markets; an educated and highly adaptive labour force; as well as liberal labour regulations (Mangoma, 2009), the current image of Zimbabwe as an investment destination is predicated on the challenges of Zimbabwe's 'lost decade'. The negative image of Zimbabwe is what currently poses as an impediment to investor confidence, and ultimately stifles FDI to Zimbabwe. As Mubaiwa (2010), the Chief Executive Officer of the Zimbabwe Investment Authority (ZIA) pointed out that, there are many challenges in promoting Zimbabwe globally, and chief amongst them being, the general negative perception of the country as a place to do business. He went on to affirm that there was a need to carefully manage this perception.

Zimbabwe's Industry and Commerce minister Mr. Welshman Ncube (2011), seemingly corroborates Mubaiwa's view, acknowledging that Zimbabwe's 'tainted' image is 'stifling' the attraction of much needed FDI into Zimbabwe. Table 1 illustrates the FDI trend of Zimbabwe in comparison to other countries in Southern Africa (2005-2011).

Table 1: Foreign Direct Investment Trends (US\$ Million)

\begin{tabular}{|l|c|c|c|c|c|c|c|}
\hline & $\mathbf{2 0 0 5}$ & $\mathbf{2 0 0 6}$ & $\mathbf{2 0 0 7}$ & $\mathbf{2 0 0 8}$ & $\mathbf{2 0 0 9}$ & $\mathbf{2 0 1 0}$ & $\mathbf{2 0 1 1}$ \\
\hline Botswana & 279 & 486 & 495 & 528 & 579 & 559 & 587 \\
\hline Malawi & 52 & 72 & 92 & 92 & 60 & 58 & 56 \\
\hline Namibia & 348 & 387 & 733 & 720 & 516 & 712 & 900 \\
\hline Mozambique & 108 & 154 & 427 & 592 & 893 & 989 & 2093 \\
\hline Zambia & 357 & 616 & 1324 & 939 & 695 & 1729 & 1962 \\
\hline Zimbabwe & 103 & 40 & 69 & 52 & 105 & 165 & 387 \\
\hline
\end{tabular}

Source: The United Nations Conference on Trade and Development (UNCTAD) 2012 Investment Report in the Zimbabwe MTP 2011-2015 Implementation Progress Report (2012)

\subsection{Nation Images}

The image of a country can be described as a picture, reputation or stereotype that is attached to a specific country (Grundey, Tolub \& Brukiene, 2006). Avraham and Ketter (2008) cited Boulding (1956) for his analysis of a nation's image being composed of four components: Cognitive (what one knows about a place); Affective (how one feels about a certain place): Evaluative (how one evaluates the place or its residents); and behavioural (whether one considers immigrating to/working in/visiting/investing in a certain place). It therefore follows that individual nations have distinct images that are unique to their particular situations, as it is these images that 'consumers' of nation offerings use to make consumption related decisions. However, as Hermann (2010) then suggests, nation images though diverse in nature more or less fall within six distinct image situations: overly attractive, positive, mixed, weak, contradictory or negative image.

Academic research by Galician \& Vestra (1987) in Avraham and Ketter (2008) found that negative news coverage has a strong effect on a nation's image. As is the case with most African nations, one finds that despite the challenge of Africa being perceived as one big country, each African country has unique image challenges stemming from often sensational media coverage, which in turn has a bearing on the attraction of FDI. Dinnie (2008) expressed the view that when a nation's image and reputation is wrought by negative events such as war, famine, poverty, corruption and chaos, even if these factors are no longer relevant, the stigma associated with the country impinges on the inflow of tourism, foreign aid and investment. 


\subsection{Investment Promotion}

The Organisation for Economic Co-operation and Development (2010) depicts investment promotion as an effective process that highlights local investment opportunities and promoting a positive image of the nation as a place to invest. , Investment promotion may be utilised to attract new investment as well as retaining existing ones, particularly in lesser known markets and nations which have experienced economic or political instability (Organisation for Economic Cooperation and Development, 2010). However, investment promotion cannot be considered as a substitute for policy and reforms, or a camouflage for fundamental economic weaknesses.

The marketing of a country for investment promotion purposes is now widely accepted as best practice; with seminal research in the field by Wells and Wint (2000) underpinning the motivation of many nations adapting marketing as a proactive approach to promoting FDI. As Wells and Wint (2000) established, promotion techniques in investment attraction consists of information provision to potential investors, the creation of an attractive image of the country as an investment destination, and the provision of services to potential investors. Otty and Sita (2011) importantly point out that African governments need to market themselves effectively, underscoring that if the image of Africa as a whole can be improved globally, FDI inflows to Africa will correspondingly improve. Investment promotion thus aims to increase the quantity of foreign investment indirectly by improving the nation's investment image (Wells \& Wint, 2000).

Odle and Gara (1997) found that the critical first step in the 3-tier stage approach (Image-building, investment generation \&investment service activities) in investment promotion is undertaking positive image building activities aimed at convincing the investor community that the country is ideal for doing business in. Countries such as Canada, Costa Rica, Jamaica, Scotland, Singapore and Thailand (Wells \& Wint, 2000); France, Egypt and Estonia (Dinnie, 2008) are cases of nations that have employed image building activities as part of an overall investment promotion program.

\subsection{Nation Branding}

The concept of 'nation branding' was developed by marketing research (Kamalova \& Konrad, 2009) and is principally the application of strategic marketing tools and techniques, applied to marketing a country/nation. De Best (2010) concedes that nation branding as an academic field is fairly new and its eminence and practice stems from the marketing field as a direct result of economic globalisation. Duah (2010) established that nation branding is a concept that encompasses the marketing techniques and strategies that a nation uses to improve, enhance and strengthen its image and reputation globally.

Contextually nation branding is the application of strategic marketing tools and marketing communication techniques, to improve or enhance a nation's image and reputation respectively among a target international audience, in a bid to enhance public diplomacy, increase trade, promote exports and tourism and ultimately boost inward foreign direct investment. African countries currently actively implementing nation branding strategies include South Africa, Botswana, Nigeria, Ghana and Kenya and as Fan (2005) asserts, a nation brand exists for every country with or without the conscious efforts of that country, as each country already has a current image to multiple audiences.

\section{Methodology}

\subsection{Research Paradigm}

The study informing this paper adopted the generic qualitative approach to research in its collection of empirical data. This approach to research is described by Caelli, Ray and Mill (2003) as a research approach, "which is not guided by an explicit or established set of philosophical assumptions in the form of one of the known qualitative methodologies." The key characteristic of the generic approach to research that made it suitable for the study is that the generic design focuses on how participants understand and make sense of their experiences, while being unencumbered by deep philosophical issues engendered in phenomenology or grounded theory for instance (Dayton \& Halloway, 2011).

\subsection{Sampling Procedure}

The primary (empirical) data collection for this study focused on investigating key perspectives of elite individuals (key informants) with regard to the potential use of nation branding as an investment promotion approach for Zimbabwe. This necessitated the gathering of exhaustive and extensive data from a purposively sampled population of elites (key 
informants) based in the purposively sampled organisations to gain in-depth knowledge without concern for representativeness and generalisation, but looking for information-rich participants central to the purpose of the study.

The universal (target) population was purposively sampled, guided by the purpose of the study and its research questions, as well as the researcher's judgment and knowledge of the target population (Tansey, 2007, Rubin \& Babbie, 2010). The researcher applied the following sampling techniques to come up with the universal sample as suggested by McMillan and Schumacher (1997):

i. Concept/theory-based sampling - the selection of information-rich persons or situations known to experience the concept or to be attempting to implement the concept/theory. With this rationalization in mind, the researcher initially purposively sampled government, quasi-government and private organizations that practice, and/or are involved in investment promotion in Zimbabwe, the rationale being that elites operate within or at the very least are associated with these organizations.

ii. Maximum variation sampling - the sample is selected to obtain maximum differences of perceptions about a topic among information-rich informants or groups. With this rationalization in mind, the researcher further purposively sampled government, quasi-government and private organizations that practice and/or are involved in investment promotion in Zimbabwe, from the pool of organizations sampled using the above mentioned procedure. This meant that the final universal sample was made up of organizations from various sectors of the Zimbabwean economy, namely industry, tourism, the financial sector, the export sector and government. This was to ensure that the study benefited from a broad spectrum of participant views and perspectives.

Ultimately the universal population was made up of the relevant Zimbabwean government ministries, quasigovernment organisations and private entities based on their involvement in; investment promotion; international trade; industry; international relations; and tourism.

From this universal sample one key informant from each organisation was identified to inform the study based on criterion sampling. Participants who were eligible and were approached to participate in the study were those who: (1) Held a senior or top managerial position within the target organization; (2) had been in the employment of the target organization for no less than 5 years; (3) had a basic appreciation of the core activities of the target organization and; (4) had a high appreciation of investment promotion and/or marketing, branding practice both personally and within the context of the purposively sampled organisation.

The participants in this study strictly met the criterion sampling conditions mentioned above. These key informants who participated in the elite interview process provided the study with in-depth perspectives on the image and current perception that exists of Zimbabwe, the role of nation branding in investment promotion, as well as nation branding in the Zimbabwean context. Interviews were conducted between the $1^{\text {st }}$ of October and 21st of December 2012, in the private offices and boardrooms of the interviewees, with each interview taking an average of 45 to 60 minutes. The sample frame and total population for the study informing this paper was $N=9$ and these are profiled in Table 2.

This study considered that literature deems small samples to be acceptable and credible in qualitative research, more-so for research that samples elites for primary data collection on the condition that the small sample provides indepth and rich data for the study, as was the case for this study and as is cited by: Merriam, (2009); Lee and Lings (2008); Crouch and McKenzie (2006); Murphy and Dingwall (2003); and Patton (2002). More specifically, Englander (2012) suggests that from a human science perspective, a qualitative study must utilize at least three participants, while Boyd (2001) cited in Groenwald (2004), regards two to ten participants or research subjects as sufficient for saturation.

Table 2: Interviewee Profiles

The Permanent Secretary in the Ministry of Economic Planning and Investment Promotion. A Permanent Secretary is one of the top three executive management positions within a Zimbabwean government ministry, along with the minister and the deputy minister of a government portfolio.

A senior official from Zimtrade. Zimtrade is an export development, marketing and facilitation organization, which operates as a quasi-government organization of the Zimbabwean government. Part of Zimtrades' mandate is export product marketing, investment sourcing as well as export marketing development for local and export oriented Zimbabwean organizations.

A senior official from the Zimbabwe Investment Authority (ZIA). ZIA is the investment promotion and facilitation arm of the government of Zimbabwe. ZIA operates as a quasi-government organization focusing on investment promotion, facilitation and after-service care for both local and foreign investors.

A senior official from Zimpapers Group. Zimpapers is Zimbabwe's leading print media house responsible for the publication 
of at least 4 of Zimbabwe's leading newspaper brands including The Herald, considered to be the mouthpiece and voice of the Zimbabwean government.

A senior official from the Reserve Bank of Zimbabwe (RBZ). The RBZ is the central bank in Zimbabwe and functions as the regulatory body of the macro financial environment of Zimbabwe implementing and regulating government policy, as well as performing an advisory role for the government.

A senior official from African Sun Tourism Group. African Sun is Zimbabwe's largest publicly listed tourism group, with operations throughout Africa. African Sun formally Zimbabwe Sun holds the operating license for Holiday Inn, as well as operating and managing hotels and tourist facilities at all of Zimbabwe's major business and leisure tourist locations.

A senior official from the Zimbabwe Tourism Authority (ZTA). The ZTA is the tourism promotion, management and regulation arm of the Ministry of Environment and Tourism of the Zimbabwean government. ZTA also performs tourism related investment promotion for infrastructure development within Zimbabwe's tourism sector.

A senior official from the Zimbabwean Ministry of Economic Planning and Investment Promotion. The ministry is mandated with the economic planning and investment promotion for the government of Zimbabwe, mainly focusing on the development, management and implementation of economic blue-prints and investment promotion for Zimbabwe.

A senior official from the Industrial Development Corporation of Zimbabwe (IDCZ). The IDCZ is a quasi-government organization that mainly focuses on industrial development planning, investment promotion and intermediary services provision within the industrial (manufacturing) sector of Zimbabwe.

\section{Source: Author's own construction}

\subsection{Data Generation}

Empirical data was collected by utilising the in-depth elite interviewing method of data collection, employing a semistructured 19 question interview schedule as the research instrument during face-to-face interviews. The semi-structured approach ensured objectivity and consistency on the researcher's part, while ensuring a certain level of standardisation of the research process and subjectivity on the participants' part. All the responses during the interviews were audio recorded, save for one interview recorded manually at the request of the interviewee. All the interviewees also with the exception of one, requested anonymity and hence the interviewees were referred to as respondent 1 to respondent 9 (R1-R9). Transcripts were compiled for data analysis from the recordings of the audio interviews and the notes collected. To ensure the internal validity of the research instrument, the interview schedule was developed as illustrated below;

Figure 1: The interview schedule development flow process

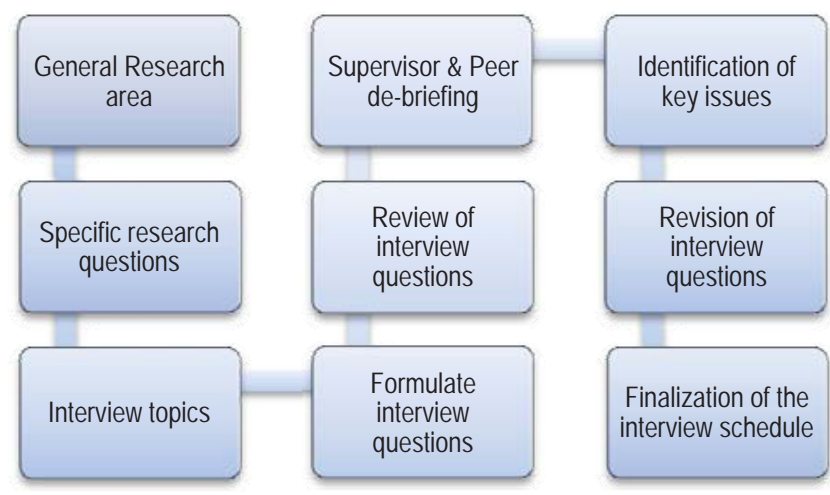

Source: Author's own construction

\subsection{Data Analysis}

The study adopted the hermeneutic approach to data analysis. Rennie (1999:5-6) describes hermeneutic data analysis as, "...the theory and practice of the interpretation of the meaning of texts." Rennie (1999: 6) goes on to suggest that the hermeneutic approach to data analysis accepts that a phenomenon is experienced by individuals in unique ways although the experience is, "...lived within a shared context." Similarly, Cole, Chase, Couch and Clark (2011:145) 
determine, hermeneutic data analysis can be defined as, "the science of interpretation." With particular reference to this study this approach took into account the fact that the Zimbabwe 'situation' as an experience affected each interviewee in a unique way thereby informing their personal perspectives, yet the experience is a shared context with all the other interviewees, meaning the researcher could make thematic comparisons and draw similarities and contradictions in their responses.

\subsection{Reliability}

The reliability of this study is the extent to which the results of the study are consistent and precise over time and are an accurate representation of the study population. To ensure the reliability of the study, the researcher: (1) Fully disclosed the research approach and epistemology of the study; (2) attempted to establish a relationship of trust with the interviewees and strove to understand their perspectives and experiences; (3) ensured the themes and interpretations from the data collected were grounded by linking them to excerpts from the interview text.

\subsection{Validity}

Validity refers to the credibility of the findings as presented by the researcher compared to the reality of the perceptions or viewpoints articulated by the respondents.

To ensure the internal validity of this study;

- The researcher did not attempt to generalize the findings of the study to different types of persons, settings and times.

- The study was conducted based on a clearly stated aim and research questions.

- The researcher obtained verbatim accounts in the language participants were comfortable in (English), from which literal statements and quotations from interviewees (primary data collection) and documents (secondary data collection) were extrapolated.

- Testimonial validity was ensured by the researcher by continuous clarification of data and interpretations thereof of the words and their meanings.

- Data was mechanically recorded (with the consent of the interviewees) using voice recording software on the interviewer's laptop.

To ensure the external validity of this study;

- The interview schedule as the data collection instrument went through rigorous research committee review process as part of the approved research proposal for this study.

- The researcher employed a universal interview schedule as the primary research instrument.

- The researcher briefed interviewees on the purpose research as well as the working definition. This ensured the informed consent of all the participants in the study.

- The informant selection process, rationale and decision process used in sampling is clearly described.

\subsection{Objectivity}

The researcher sought to avoid conscious and unconscious bias by taking the following steps:

- All interviews were conducted utilizing the pre-determined, peer reviewed interview schedule, from which the researcher did not deviate.

- The researcher employed the hermeneutic approach to data analysis which focuses on the rigorous review of data and dictates the use of participant's own words to qualify their views or perceptions.

- Peer de-briefing was utilized by selecting a PhD colleague to review the logical analysis of data and its interpretation.

\section{Results and Discussion}

The data collected during the course of this study was generated in a methodical manner and was objectively analysed guided by the hermeneutic approach to data analysis. The following are the key findings (themes) that emerged from the study: 


\subsection{Finding 1}

Zimbabwe has a predominantly negative image as an investment destination and has at best a contradictory image as a nation.

Interviewees had both positive and negative word associations with Zimbabwe as a brand, with Zimbabwe being associated with words such as amazing, dynamic, resourceful, friendly, rich and developmental summing up the positive association with Zimbabwe. On the other hand some of the interviewees associated Zimbabwe with negative words such as sanctions, violence, hunger, instability, policies and indigenization. The description of Zimbabwe in reference to individual traits drew descriptions such as, resilient, innovative, intelligent, hospitable, misunderstood and adaptive, while other interviewees characterised Zimbabwe as going through changes, confused, always shooting his own foot and having no sense of direction.

An almost similar approach to contextualising a nation's brand image was used by Freemantle (2007), who employed the juxtaposition of positive and negative attributes in his study Brand South Africa: Dutch impressions of the 'Rainbow Nation'. In seeking to gauge the strongly negative versus the strongly positive perceptions of South Africa, the study presented participants a table with five countries; New Zealand, Canada, India, South Africa and interestingly Zimbabwe. Participants were given a defined list of adjectives to associate these countries with and according to the study Dutch impressions of Zimbabwe were that of, "...Poverty, Crime, Weakness, Racism, Autocracy and Laziness." (Freemantle, 2007) although these were the top six labels of Zimbabwe, $61 \%$ of the Dutch respondents associated Zimbabwe with the word 'Filth' Freemantle (2007). Although this finding cannot be inferred to represent the perceptions of foreign investors, the findings are an indication of the perceptions that existed of Zimbabwe in 2007 and such perceptions may still be at play.

The findings of this study also suggest that Zimbabwe has a negative brand image as an investment destination and that both the local [Zimbabwean] and foreign media have a significant role in the formation of the current image of Zimbabwe. For instance (R1) ascertained that, "largely I would say its [Zimbabwe's image as an investment destination] negative internationally. I don't want to use the word controversial, so I would say negative." With particular reference to the role of the media in this negative image, all the respondents were of the opinion that the media had and continue to have a significant role in informing perceptions of Zimbabwe. For instance (R2) pointed out that, "... both local and foreign media plays a pivotal role because the media has got a serious role in shaping opinion and they shape opinions in either direction, negative or positive direction." (R1) expressed the same view elucidating that the media has a very strong bearing on, "...the perception of the country by outsiders."

In his study on nation branding for Ethiopia, Kidane (2010:56) found that in the case of Ethiopia and its image, "Even though poverty is a real problem in the country, many believed that it has been magnified and talked [about] repeatedly to spoil the image rather than solve the problem...the NEWS by nature focuses of negative aspects unless it is from a government and media which shows its development sometimes mixed up with propaganda." The study also indicated that the interviewees expressed a similar opinion that the media had a major influence on the brand of a country. (Kidane, 2010).

\subsection{Finding 2}

The image of Zimbabwe as a nation in general and as an investment destination has a considerable effect on its ability to attract FDI and its investment promotion efforts.

An emergent theme from this study was that while Zimbabwe has a myriad of investment opportunities for both current and potential investors, Zimbabwe faces a multitude of challenges in investment attraction and promotion stemming from its current nation brand image. With that in mind it is safe to say that one cannot separate brand Zimbabwe from its offering to consumers (investors) and that Zimbabwe needs an enabling environment before initiating a nation branding program.

Amongst the investment opportunities identified by the respondents were opportunities to invest in value addition and the beneficiation of Zimbabwe's natural resources such as minerals (diamonds and platinum) and agricultural produce like cotton and tobacco. Zimbabwe' geographical location, at the centre of both SADC and COMESA regional blocks presents market-seeking investors a unique and very attractive opportunity to access multiple international markets from one central location. However, given Zimbabwe's challenges, the country is unable to attract meaningful FDI. Challenges identified by interviewees included the uncertain political situation in Zimbabwe, negative publicity and more importantly the negative image Zimbabwe has as a country and as an investment destination. As (R9) asserted, 
"...the first one [challenge] is the image of the country. You are aware that between1998-2008 we [Zimbabwe] were regarded as a pariah state and people would not invest in the country because of the politics, because also because of the downturn in the economy...people want to invest in a growing economy..."

With this theme in mind, it also emerged that there is a co-relation between the image of Zimbabwe and its ability to attract FDI, in as much as Zimbabwe's image as an investment destination has a causal effect on the country's ability to attract FDI. It also emerged that the image of Zimbabwe has an influence on the type of investment Zimbabwe attracted. According to (R4), "...there is a causal relationship with the image causing the investment to come to the country", which at this point in time is very little compared to other countries in the region. As (R2) illustrated, "Zambia is looking at around US\$9 billion, Mozambique US $\$ 16$ billion, Angola between US\$26-27 billion in investment inflows, while Zimbabwe is at a modest US\$328 million." Given this trend (R9), mentioned that his ministry was aware of the correlation between the image of Zimbabwe and FDI inflows and had visited no less than eight major investor countries and hosted investment seminars as an approach to improving the image of Zimbabwe as a place to invest.

A study by Kamalova and Konrad (2010), found that the Nation Brand Index (NBI ${ }^{\mathrm{TM}}$ ), a subjective nation brand assessment and analytical tool based on the Nation Brand Hexagon (NBH), was statistically significant and had a positive influence on FDI inflows to a country. Their study pointed to the fact that the $\mathrm{NBI}{ }^{\mathrm{TM}}$ as a measure of intangibles (brand image and perceptions) in an investment destination had a predominantly positive effect on FDI. Kamalova and Konrad (2010) found that a one-point increase in the $\mathrm{NBI}^{\mathrm{TM}}$ could be associated with a $27 \%$ increase in the inflows of inward FDI to a particular country. "FDI flows into a host country rise as its nation image, the value of its intangibles improves" (Kamalova and Konrad, 2010). These findings substantiate the views of the respondents in this study that there is a causal relationship that exists between the image of Zimbabwe and ability to attract FDI.

\subsection{Finding 3}

Marketing and branding tools can be utilized to manage the image of Zimbabwe for investment promotion purposes.

Corporate enterprises have for decades been able to add value to their products and services based on their effective use of marketing and branding techniques. It also emerged that marketing and branding techniques such as advertising, personal selling, public relations and sales promotion facilitate the projection of Zimbabwe as a nation and as an attractive investment destination, thereby positively influencing investor perceptions. As (R6) highlighted, "...its [marketing and branding tools] how we project ourselves outside the country. If we want people to change their perception we must invite them to Zimbabwe to see for themselves." (R6).

The literature review revealed that there is a general view that African governments need to market themselves effectively, given that they (African governments) compete for FDI in a global marketplace dominated by nations with highly effective marketing programs (Otty and Sita, 2011). In investment promotion the use of targeted marketing tools is recommended for investment generation purposes, but more importantly in the image-building activities of nations. The seminal study by Well and Wint (2000) found that it is for countries to use image-building techniques to simply change a country's image as a place to invest, with cases including those of Costa Rica, Jamaica, Scotland and Singapore.

Marketing and branding techniques improve the images of nations by offering approaches to effectively manage images and create value for 'consumers' in nation branding. The functionalist approach to nation branding draws parallels between the creation and management of nation images and more the traditional practice of product and corporate branding (Kaneva, 2011). As Porter (1989) summarised, due to globalisation many nations have found it necessary to proactively strategise and brand themselves in an effort to augment their images as a source of competitive advantage in investment promotion.

\subsection{Finding 4}

Nation branding can be considered to be the nexus of Zimbabwe's turnaround as an investment destination.

In the Zimbabwean context nation branding is viewed as a tool for re-branding Zimbabwe as an investment destination. As (R5) suggested, the 'good' thing about Zimbabwe is that everyone knows about us, albeit for predominantly negative reasons, "So what now? What we are supposed to do as a nation in terms of re-branding is the use of that awareness to reposition the country using re-branding techniques, because everyone knows us [Zimbabwe], let's reposition using our positives." Similarly, (R1) declared, "I certainly think we [as Zimbabwe] need to rebrand... maybe not completely, but there is a need for re-branding".

It also emerged from the study that, the utilisation of nation branding would facilitate the re-packaging and 
dissemination of Brand Zimbabwe as an attractive investment destination. (R1) established that, "...if you have got a good brand it is easier for FDI to come into a country," maintaining that Zimbabwe must take the initiative to market and reach out to investors by giving investors the correct information. As (R2) added, "...we [must] go to mount promotional campaigns to say these are the investment opportunities that are here in Zimbabwe, better still we go with packaged [investment] products." Finally (R3) believed that the role of marketing and branding in the facilitation of FDI was embarking on a long-term program to inform the right investors at the right time of investment opportunities in Zimbabwe on a sustained and consistent basis.

The case of Estonia (Dinnie, 2008) illustrates how nation branding can be utilised as a re-branding tool for investment promotion. Little known Estonia sought to revamp its image arguing that consumers and stakeholders being informed of a new compelling and distinctive 'Brand Estonia' would generate interest in the country and 'forge' an attractive reputation for Estonia (Dinnie, 2008). Brand Estonia employed nation branding as, "... a systematic means to communicate positive and valuable ideas about the country, particularly foreign audiences, in a way that will position Estonia favourably and competitively" (Dinnie, 2008). One key objective of Brand Estonia was to promote FDI. The case of Estonia substantiates the view that nation branding may be employed as a re-branding strategy for FDI promotion.

\section{Conclusions}

Based on the research questions and findings of the study the following conclusions with regards to nation branding as a foreign direct investment promotion strategy for Zimbabwe can be made;

1. Zimbabwe has a predominantly negative image as an investment destination and a contradictory image as a nation in general. These images have a significant effect on the country's ability to attract FDI and its investment promotion efforts.

2. We also conclude that marketing and branding techniques have practical applications in the promotion of the image of Zimbabwe and that nation branding as a combination of these techniques is the nexus of Zimbabwe's turnaround as an investment destination.

3. The relevant government and private sector stakeholders in investment promotion in Zimbabwe categorically agree that nation branding is a potential and relevant, proactive investment promotion approach for Zimbabwe and the government.

4. Nation branding is the application of strategic marketing tools and marketing communication techniques to improve or enhance a nation's image and reputation respectively, amongst a target international audience in a bid to enhance public diplomacy, increase trade, promote exports and tourism, and ultimately boost inward foreign direct investment (FDI).

5. The technical-economic approach in nation branding has evolved to become a commercial concept due to a more homogenous global market characterised by global competition with nation branding assuming the role of the tool utilised by nations to attract investment, tourists, human capital or trade.

6. In an increasingly globalised world the role of nation branding in facilitating FDI is that nation branding assumes the symbolic meaning to investors as the development of a value proposition (brand) that represents the multidimensional intangible value of a nation in comparison to other nations, thereby creating competitive advantage and differentiation.

7. Finally the findings of this study lead us to the conclusion that nation branding is indeed a feasible strategic image promotion strategy for the government of Zimbabwe, necessary to proactively promote investment and attract increased FDI inflows to the country.

\section{Recommendations}

We offer the following recommendations particularly to the government of Zimbabwe based on the data analysis, findings and conclusions of this study based on the proposed Nation Brand-based Investment Promotion Model (Figure 2).

1. We recommend that the government of Zimbabwe strongly consider the initiation and development of a nation branding strategy aimed at revamping the image of the country as a whole, accentuating the positive image of Zimbabwe while simultaneously trying to change the realities that give rise to its negative image (The first step in Nation- Brand Identity development).

2. Once the government of Zimbabwe has established a nation branding program we recommend that the government through its Ministry of Economic Planning and Investment Promotion and its stakeholders work 
out a long-term strategy for a more positive investment destination profile via concrete developments and improvements on the problematic fields and the allocation of budgets to investment brand image development activities. This implies creating an enabling environment for investment and effectively marketing it thereof. (The second step in Nation- Brand Identity development).

3. Given Zimbabwe's financial constraints we recommend that Zimbabwe need not re-invent the wheel in nation branding strategy as such, and instead adopt the existing best practices and strategies implemented by other nations such as South Africa, Estonia, Egypt, France and Kenya. (Investment promotion mix Communicators of Nation Branding Identity).

4. We also recommend that Zimbabwe's nation branding be implemented as a multi-stakeholder [government, business, individuals and NGO's] program managed by the right people with the requisite skills. It is paramount that the initiative be inclusive and apolitical. Zimbabwe must identify acceptable brand ambassadors in the form of products and/or individuals to effectively communicate with Zimbabwe's target audience in an integrated marketing communication approach. (Communicators of nation Branding Identity).

5. The overall success of Zimbabwe's investment promotion lies in the country's ability to effectively brand itself as an investment destination and provide the right investment packages to the right investors. (Nation-brand Image).

Figure 2: Nation Brand-based Investment Promotion Model

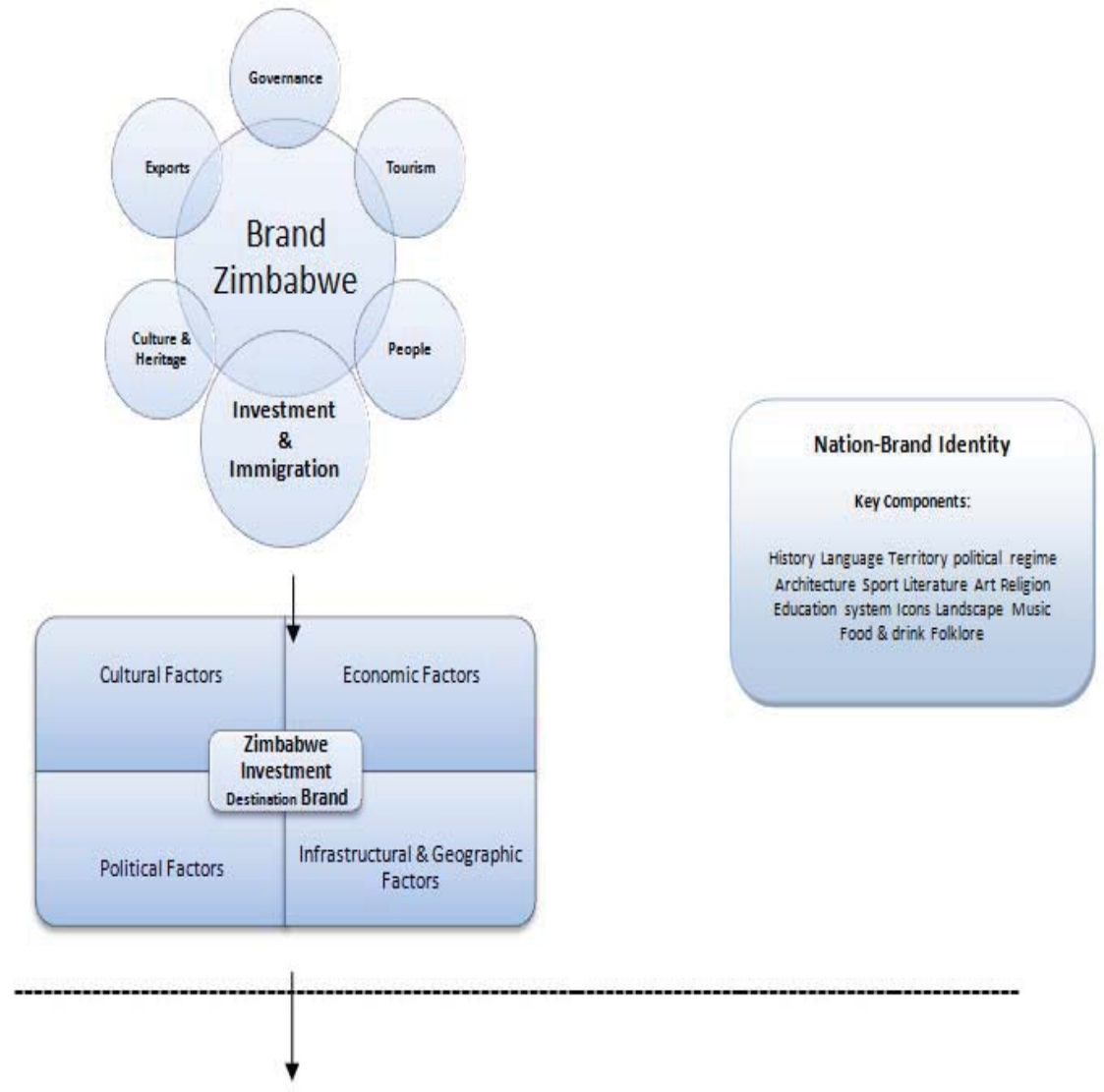




\section{Investment Promotion Mix}
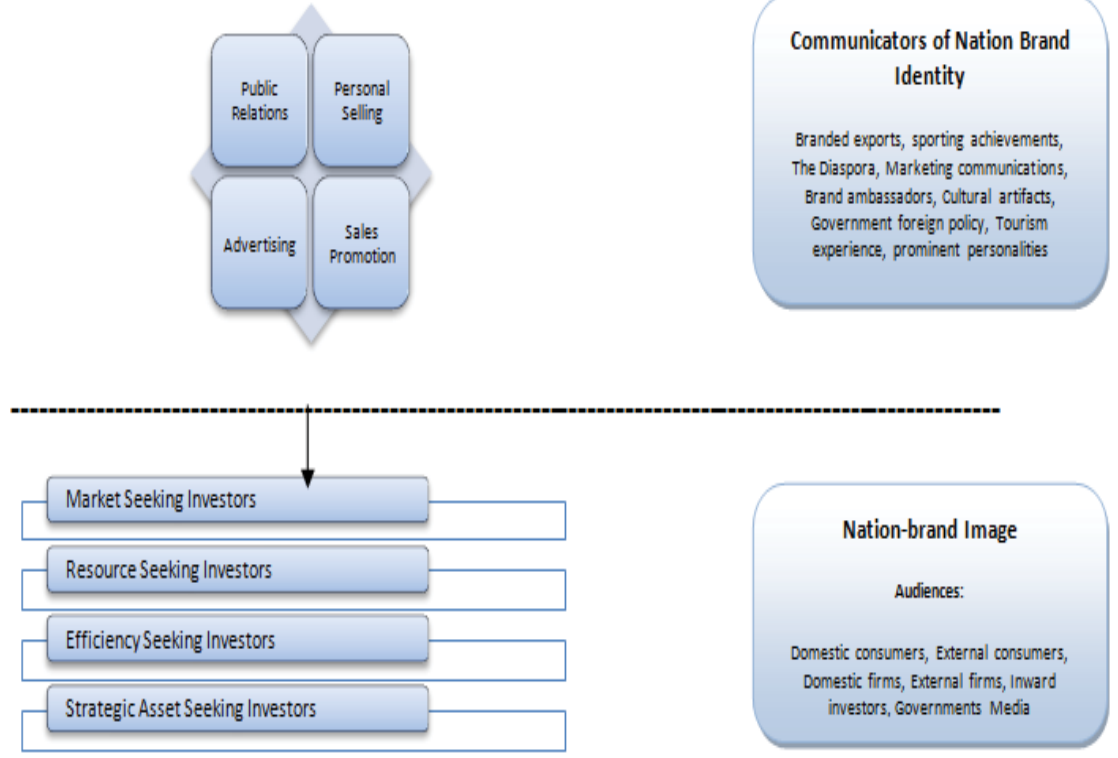

Source: Authors own construction with reference to work by Kaneva (2011) and Dinnie (2008).

\section{Contributions of the Study}

This study provided evidence to the effect that in the case of Zimbabwe, its enduring negative image as a result of the crisis between 1998 - 2008 is a significant hindrance to the attraction of FDI and to a larger extent the inability of Zimbabwe to, to date adequately finance its Medium Term Plan 2011 - 2015 through FDI. This study has contributed towards providing a strategic option for the government of Zimbabwe in its endeavour to promote the country for investment purposes by exploring the perspectives of key informants in investment promotion within Zimbabwe. From these perspectives and a review of relevant literature, this study has been able to suggest the underlying reasons for the challenges Zimbabwe faces in attracting FDI and ultimately the feasibility of nation branding as a panacea to these challenges for Zimbabwe.

Theoretically, it is our hope that this study contributes somewhat to the clearer understanding of nation branding in the context of investment promotion while adding to the growing body of knowledge in the field of nation branding. It is also our hope that the generic model for nation branding that this study has recommended for Zimbabwe also positively contributes to the Zimbabwean brand strategy and to the growing body of theory in nation branding.

\section{References}

Adler and Adler [s.a] in Baker, Sarah. E. \& Edwards Rosalind [s.a]. How many qualitative interviewers are enough? Expert views and cases in qualitative research. National Centre for Research Methods.

Avraham, E and Ketter, E. (2008). Media strategies for marketing places in crisis: Improving the image of cities, countries and tourist destinations. Oxford: Butterworth-Heinemann

Baker, Sarah. E. \& Edwards Rosalind [S.a]. How many qualitative interviewers are enough? Expert views and cases in qualitative research. National Centre for Research Methods.

Bellosso, J.C. (2010). Country brand. A differentiation mechanism and source of intangibles. Paradigmes, 5, 44-51.

Boulding (1956) in Avraham, E and Ketter, E. (2008). Media strategies for marketing places in crisis: Improving the image of cities, countries and tourist destinations. Oxford: Butterworth-Heinemann

Boyd, C.O. (2001). In Groenwald T. (2004). A Phenomenological Research Resign Illustrated. International Journal of Qualitative Methods 3(1).

Caelli, Kate, Ray Lynne \& Mill Judy. (2003). 'Clear as Mud': Toward greater clarity in generic qualitative research. International Journal of Qualitative Methods 2(2). 
Cerswell, J.W. (1998). Qualitative inquiry and research design. Choosing among 5 traditions. Thousand Oaks. CA: Sage.

Cixous and Galle (1997) in Kinsella, Elizabeth, Anne. (2006). Hermeneutics and critical hermeneutics: Exploring possibilities within the art of interpretation [47 paragraphs]. Forum Qualitative Socialforschung/Forum: Qualitative Social Research, 7(3). Art 19. [Online] Available: http://nbn-resolving.de/um:nbn:de:0114-fqs0603190. (January 1, 2013).

Cole, Caroline, Chase, S. Couch, O. \& Clark, M. (2011). Research methodologies and professional practice: Considerations and Practicalities. The Electronic Journal of Business Research Methods. 9(2), 141-151.

Crouch, M. \& McKenzie, H. (2006). The Logic of Small Samples in Interview Based Qualitative Research. Social Science Information 45(4), 483-499.

Dayton, Christine and Halloway, Immy. (2011). Qualitative research methods in public relations and marketing communications. (2nd ed.). New York: Routledge Publishing:

De Best, Maya. (2010). Who shapes the image of the Netherlands? An analysis of the stakeholders that influence the image of a country. Master's Thesis. Erasmus University, Rotterdam. Faculty of history and Art. August 1 2010. [Online] Available: www.oaithesis.eur.nl/ir/repub/asset/8061/Thesis_mdebest_final20100820.pdf. (April 13, 2011).

Dinnie, K. (2008). Nation Branding: Concepts, Issues, Practice. Oxford: Butterworth-Heinemann.

Duah, Agyeman, Rachel. P. (2010). Nation branding as a tool for the increase of foreign direct investment. Dissertation BSc Business Administration. Ashesi University College. Ghana.

Englander, .M. (2012). The Interview: Data Collection in Descriptive Phenomenological Human Scientific Research. Journal of Phenomenological Psychology, 43, 2012. 13-35.

Fan, Y. (2005), Nation Branding: What is Being Branded? Journal of Vacation Marketing, (12)1, 5-14.

Fan, Y. (2009). Branding the nation: Towards a better understanding. Brunel University Business School. Brunel University, London.

Freemantle, S.A.C. (2007). Brand South Africa: Dutch impressions of the 'Rainbow Nation'. Thesis: Master of Arts (International Relations). University of Stellenbosch, South Africa.

Galcien and Vestra (1987) in Avraham, E and Ketter, E. (2008). Media strategies for marketing places in crisis: Improving the image of cities, countries and tourist destinations. Oxford: Butterworth-Heinemann.

Gray, D.E. (2009). Doing research in the real world, (2nd ed.). London: Sage Publications Inc.

Grundey, Dianora, Tolub, B \& Brukiene, J. (2006). Country image as a marketing tool for fostering innovation and entrepreneurship. Kaumas Faculty of Humanities. Vilnius University. Lithuania.

Hancock, Beverly (1998). Trent focus for research and development in primary healthcare: An introduction to qualitative research. Trent Focus Group. [Online] Available: www.faculty.cbu.ca/pmacintyre/course_pages/.../IntroQualitativeResearch.pdf. (May 10, 2011)

Hermann, Anna-Marie, B. (2010). Competitive identity management - symbolic capital promotion and accumulation by public policy based mental mapping (GM-S.C.P \& A): Nation branding and public diplomacy in Sweden. Doctoral thesis. University of Wien.

Johnston (2008) cited in Dinnie, K. (2008). Nation Branding: Concepts, Issues, Practice. Oxford: Butterworth-Heinemann.

Kalamova, Magarita.M and Konrad, K.A. (2010). Nation brands and foreign direct investment. Research Paper: Max-Planck-Institute for Intellectual Property Rights, Competition and Tax Law. Berlin: The Social Science Research Centre.

Kaneva Nadia. (2011). Nation Branding: Toward an agenda for critical research. International Journal of Communications, 5(2011), 117141.

Kazembe, P and Namizinga, N. (2007). The impact of foreign direct investment on development: Policy challenges for Malawi. The government of Malawi, ministry of industry, trade and private sector development. Integrated framework policy analysis working paper series No.6.

Kidane, G.K. (2010). Branding Ethiopia: Opportunities and Challenges. Research Report, Masters Degree in Business Leadership. University of South Africa (UNISA).

Kinsella, Elizabeth, Anne. (2006). Hermeneutics and critical hermeneutics: Exploring possibilities within the art of interpretation [47 paragraphs]. Forum Qualitative Socialforschung/Forum: Qualitative Social Research, 7(3). Art 19. [Online] Available: www.nbnresolving.de/um:nbn:de:0114-fqs0603190. (January 1, 2013).

Lee, N. \& Lings, I. (2008). Doing Business Research: A Guide to Theory and Practice. London: Sage Publications Ltd.

Mangoma, E. Hon. (2009). Investment opportunities in Zimbabwe. Presentation by the Ministry of Economic Planning and Investment Promotion of Zimbabwe. Presented on 30th March 2009.

McMillan, J.H \& Schumacher, J.S. (1997). Research in Education: A Conceptual Introduction. New York: Longman.

Merriam, Sharan.B. (2009). Qualitative Research: A Guide to Design and Implementation. San Fransisco: Jossey-Bass.

Mubaiwa, R. (2011) in Mafirakurewa, M. (2011). Image stifling investment attraction. News Day Newspaper, 11 January: 2011.

Mubaiwa, R. (2012). ZIA Optimistic. Herald Online. [Online] Available: http://herald.co.zw/index.php?view=article\&catid $=41 \% 3$ Abusiness\&id=55211. (October 18, 2012)

Murai, Y. (2011). 'Alive with Possibility'. Brand South Africa and the discursive construction of South African identity. Media @ LSE Economics. MSc Dissertation, London School of Economics.

Murphy, E. \& Dingwall, R. (2003).Qualitative Methods and Health Policy Research. New York: Walter de Gruyter Inc.

New Ziana (2012). Zim ranks top three African investment destination. www.harare24.com.index-id-business-zk-13066.ht. (August 12, 2013)

Nyakazeya, P. (2010). Investment: 'Zim perception needs addressing'. The Financial Gazette- Business Digest, 17-23 December: 7.

Odle, M and Gara, J. (1997). Survey of best practices in investment promotion. The United Nations Conference on Trade and Development (UNCTAD). [Online] Available: www.unctad.org/asit (June 8, 2011) 
Organisation for Economic Co-operation and Development (OECD). (2010). Policy framework for investment toolkit. Investment promotion and facilitation. The Investment Division of the OECD Directorate of Financial and Enterprises Affairs.

Otty, M \& Sita, A. (2011). Its time for Africa. Ernst \& Young 2011 Africa attractiveness survey. Oxford Economics.

Patton, MQ. (2002). Qualitative Research and Evaluation Methods, (3rd ed). California: Sage Publications Inc.

Porter, M. (1989). The competitive advantage of nations. New York: Simon \& Schuster Trade.

Rennie, D.L. (1999). Qualitative research: a matter of hermeneutic and the sociology of knowledge. In Kopala, M. \& Suzuki, L.A (eds). Using qualitative methods in psychology, pp3-13. Thousand Oaks: Sage.

Rubin, A \& Babbie, E. (2010). Essential Research Methods for Social Work, 2nd Edition. Belmont: Brooks/Cole.

Selamat, M.H \& Hashim, A.H. (2008). A qualitative decision trail in hermeneutic analysis evidence from the case study. International Journal of Business Management, 3(3), 41-55.

Sulaiman, T. (2012). Foreign direct investment into Africa to double by 2014: UN. Article from Thomson Reuters. [Online] Available: http://www.reuters.com (January 15, 2013)

Tansey, O. (2007). Processing, Tracing and Elite Interviewing: A Case for Non-probability Sampling. Journal of Political Science and Politics, 40(4).

Tech (1994) in Gray, D.E. (2009). Doing research in the real world (2nd ed.). London: Sage Publications Inc.

Wells, L, T and Wint, A, G. (2000). Marketing a country: Promotion as a tool for attracting foreign investment. Revised Edition (March 2000). Foreign Investment Advisory Service. Occasional Paper 13. [Online] Available: www.rru.worldbank.org /documents/paperslinks/244.pdf. (May 8, 2010)

Zimbabwe Independent Newspaper (2012). Zim a destination for the brave. [Online] Available: www.theindependent.co.zw/2012/11/16 Izim-a-destination-for -the-bravel (August 12, 2013).

Zimbabwe Independent Newspaper (2013). Unabated sabotage of investor confidence. [Online] Available: www.theindependent.co.zw/2013/04/12/unabated-sabotage-of-investor-confidence-2/ (August 12, 2013).

Zimbabwe Medium Term Plan 2011-2015. (2011). Ministry of Economic Planning and Investment Promotion. Printflow Pvt Ltd: Zimbabwe. 